\title{
Cross-Border cooperation in the Rhine-Meuse region: Aachen (D) and Heerlen (NLs)
}

\section{Some considerations from a law and economics perspective on a future European Grouping of Territorial Cooperation}

\author{
Simon Duindam • Lisa Waddington
}

Published online: 18 November 2010

(C) The Author(s) 2010. This article is published with open access at Springerlink.com

\begin{abstract}
This article considers the role of land in (regional) development and the financing of such development. Specifically the article reflects on the application of legal provisions relating to the use of land and development, including considering how fiscal instruments can be used to promote economic development in a crossborder legal entity. The article concludes with recommendations as to how crossborder economic development can be improved. The article takes as its starting point the intention of the regions of Parkstad Limburg (NLs) and Aachen (GER) to establish a European Grouping for Territorial Cooperation (EGTC), with a view to promoting cross-border economic and spatial development.
\end{abstract}

Keywords Regional development - Land - European grouping for territorial cooperation · Cross-border cooperation

JEL Classification K00

\section{Introduction}

Recently seven municipalities in the south-east of the Netherlands (the Province of Limburg), called Parkstad Limburg (250.000 inhabitants), bordering the Aachenregion in Germany (570.000 inhabitants), decided to form a new development

A draft of this paper was presented at the seminar in honour of the 90th birthday of Reginald Hansen in Zeulenroda (Germany) on 16 November 2009.

S. Duindam $(\bowtie)$

Local Auditing Chamber Parkstad, Limburg, The Netherlands

e-mail: simon.duindam@ipki.nl

L. Waddington

Department of International and European Law, Maastricht University, Maastricht, The Netherlands 
agenda, called the Pact van Parkstad. ${ }^{1}$ The focal point of this agenda is the execution of a public agenda, that has already been developed from a policy perspective. The agenda mainly consists of plans for economic and spacial developments in the area of Parkstad Limburg, including the restructuring of the housing volume and public provisions, adapting it to a sharply shrinking population and household base, the construction of new railways lines and a $27 \mathrm{~km}$ ringroad, the redevelopment of industrial estates and the development of several new tourist attractions. Pact van Parkstad amounts to a large and impressive restructuring and development agenda, not only in volume, but also in time.

To structure this agenda politically and legally, the Pact van Parkstad agenda will be organised in the form of a Collective Public Agreement (Gemeenschappelijke Regeling), with a Public Company (Overheids NV) that will manage the practical day-to-day activities. ${ }^{2}$

The content of the Pact van Parkstad agenda is not only interesting from a governance perspective, but also from an economic perspective. The question arises as to whether the legal entity responsible for implementing the Pact van Parkstad agenda can guarantee the property rights of the economic and spatial developments? However, this is not the only interesting element from a law and economics perspective. Of interest is also the role of land in (regional) development and the financing of the Pact van Parkstad. Moroever, the application of legal provisions to the use of land and development, for example the way in which fiscal instruments can be used to promote economic development in a cross-border legal entity, are also worth considering. This article will reflect on all of these issues, and will integrate the various insights in order to reach some observations. These observations will lead to the making of specific recommendations about how cross-border economic and special development, through the use of a specific agenda such as the Pact van Parkstad, can be improved. This article will try to answer these questions, not only with regard to Parkstad Limburg itself, but also with regard to a similar entity in neighbouring Aachen in Germany. Both regions wish to be connected through a European Grouping for Territorial Cooperation (EGTC). ${ }^{3}$

The EGTC is a new EU legal instrument designed to facilitate and promote crossborder, transnational and interregional cooperation. ${ }^{4,5}$ Unlike the structures which

\footnotetext{
${ }^{1}$ Het Pact van Parkstad, http://www.parkstad-limburg.nl/ (last accessed 5 June 2010).

2 See Rekenkamercommissies Parkstad Limburg, Het Pact van Parkstad (2009), available at: http://www.rekenkamersparkstadlimburg.nl/ (last accessed 5 June 2010).

3 Representatives of the local municipalities in Limburg (Parkstad Limburg) and Aachen (City of Aachen and and the Region of Aachen) signed a statement of intent, expressing their desire to develop an EGTC, on 19 October 2009. See: Ondertekening Intentieverklaring EGTS, available at: http://www.parkstadlimburg.nl/index.cfm/parkstad-limburg/informatie/nieuws/nieuwsartikel/Ondertekening-intentieverklaringEGTS (last accessed 5 June 2010).

4 See Regulation (EC) No 1082/2006 of the European Parliament and of the Council of 5 July 2006 on a European grouping of territorial cooperation (EGTC), O.J./L 210/19. Article 1(2) of the Regulation provides: "The objective of an EGTC shall be to facilitate and promote cross-border, transnational and/or interregional cooperation ... between its members ... with the exclusive aim of strengthening economic and social cohesion."

5 See also Gianluca Spinaci and Gracis Vara-Arribas, The European Grouping of Territorial Cooperation (EGTC): New Spaces and Contracts for European Integration?, EIPASCOPE 2009/2, 5 and Committee of
} 
governed this kind of cooperation before 2007, the EGTC is a legal entity and, as such, enables national, regional and local authorities and other public bodies, ${ }^{6}$ from different Member States, to set up cooperation groupings with a legal personality. The EGTC is unique in the sense that it enables public authorities of various Member States to team up and deliver joint services, without requiring a prior international agreement to be signed and ratified by national parliaments. Member States must however agree to the participation of potential members from their respective countries. EGTCs can make binding decisions on a wide variety of cooperation issues and covering a large territory. Since they have legal personality, they can employ staff, own property and participate in legal proceedings. As one set of commentators have noted: "This legal stability reinforces decision-making among the partners, their position in interaction with the EU institutions, their possibilities for launching or improving their international position and the effective management of cooperation programs and projects." 7 The law applicable to the acts of the EGTC is that of the Member State in which EGTC has its registerd office. ${ }^{8}$

In this article we will first take a look at the different characteristics of a Collective Public Agreement (Sect. 2). This will be followed by an economic analysis of land value and development issues (Sect. 3). In Sect. 4 the financial resources for development and restructuring the Parkstad-Limburg/Aachen region will be considered. Before reaching a conclusion and further observations in Sect. 6, we will address several issues related to the functioning of a cross-border authority and an EGTS designed to support the redevelopment of the region (Sect. 5).

\section{The characteristics of a collective public agreement}

The way in which a government and the citizens in a certain area interact with, and view, each other is of great importance for the design of institutional structures in the public domain. If we put the needs of the citizens first, then the design of the institutional structures and the research on such structures should focus on the way

\footnotetext{
Footnote 5 continued

the Regions, The European Grouping of Territorial Cooperation (EGTC): state of play and prospects, available at: http://portal.cor.europa.eu/egtc/en-US/Publications/Pages/welcome.aspx (last accessed 4 June 2010).

${ }^{6}$ Regulation (EC) No. 1082/2006 provides that bodies governed by public law within the meaning of Article 1 of Directive 2004/18/EC on the coordination of procedures for the award of public works contracts, public supply contracts and public service contract can be members of an EGTC (Article $3(1)(d))$. Therefore public bodies which are subject to EU public procurement rules are eligible for membership of an EGTC.

7 Gianluca Spinaci and Gracis Vara-Arribas, The European Grouping of Territorial Cooperation (EGTC): New Spaces and Contracts for European Integration?, EIPASCOPE 2009/2, 5 at 6.

${ }^{8}$ In this respect, Article 2(1) of Regulation (EC) No. 1082/2006 provides that "Where it is necessary under Community or international private law to establish the choice of law which governs an EGTC's acts, an EGTC shall be treated as an entity of the Member State where it has its registered office". Various other provisions of the Regulation also refer to the jurisdiction and competent authorities of the Member State in which the EGTC has its registered office, see e.g. Arts. 6 and 15.
} 
public services meet the needs of individuals. ${ }^{9}$ Research in this area, such as that carried out by local auditing chambers, focuses on the evaluation of actual policies with regard to their effective and efficient delivery of one or several products or services in a certain field, neighbourhood or sector. ${ }^{10}$ A local government can provide such products and services through its own employees, by subsidizing or contracting out the work to other parties, or by setting up a so-called Allied Party.

In an increasingly complex society, local governments have many ways in which to work together with other parties. Sometimes the local government is financially and managerial attached to such a party, because it owns such a party, or is part of the board of such a party, and so we speak about an Allied Party (Verbonden Partij). ${ }^{11}$ Examples of such Allies Parties are organisations that collect refuse in several municipalities, social services, the fire services etc.

In Parkstad Limburg, as elsewhere, some goods and services must be provided collectively, since it is necessary that all individuals in the region have access to the services. Examples of such services are the police and fire services. In addition, (local) government must impose restrictions on private suppliers of certain goods and services, to ensure that the action of one party does not cause negative effects on another party. In the case of negative external effects the government must be the supplier of the necessary collective goods, or must impose certain rules on other providers in order to combat negative external effects. An example of such an Allied Party is the Dutch Regional Health Service $(G G D)$.

The need for collective goods and cooperation and the need to prevent that the efforts of one entity will benefit another, without any payment being made by that second party, have led to a large number of Collective Public Agreements in the Netherlands. This is a specific form of Allied Party involving the local government, in which several municipalities work together. Examples of Collective Public Agreements are the local fire services and the Regional Health Services; however, for economic and development purposes the most important regional Collective Public Agreements in Parkstad Limburg are the regional cooperation entity Parkstad Limburg $^{12}$ (same name), Eurode ${ }^{13}$ (a cross-border organisation between the cities of Kerkrade (NL) and Herzogenrath (D)), and the sheltered workshops for people for disabilities. ${ }^{14}$

An important characteristic of a collective agreement is that all costs and benefits of this agreement are covered by, or attributable to, the members of the collective. ${ }^{15}$ Often, such agreements function well, but sometimes it is necessary for the local authority to provide significant financial support, such as through subsidies, to keep

\footnotetext{
${ }^{9}$ Harvey S. Rosen, Public Finance, 6th edition (McGrawHill, 2002), chapter 1.

${ }^{10}$ See for example the goal of local auditing chambers in Parkstad Limburg available at www. rekenkamersparkstadlimburg.nl.

${ }^{11}$ Het Verband met Verbonden Partijen, Rekenkamercommissie Parkstad Limburg, 2007. This report is available at: http://www.rekenkamersparkstadlimburg.nl/ (last accessed 5 June 2010).

12 Ibid., page 83.

${ }^{13}$ Ibid., page 82.

${ }^{14}$ Ibid., page 92.

15 Rosen, chapter 4.
} 
the collective good afloat. This is often the case because these collective agreements provide goods or services which are too risky, from a financial perspective, for the private sector to provide. $^{16}$

Allied Parties are professional organisations. Their place in the public-private arena has given them the possibility to translate their experience with tasks and customers into a sustainable provision of products and services. ${ }^{17}$ Allied parties are capable of being innovative for longer periods, thereby ensuring their long-term existence. $^{18}$

\section{An analysis of land value and development issues}

When developing a railway line, roads, or restructuring a certain area, future revenues are not limited to the sale of tickets, collection of tolls or value of the real estate. This is because, for example, the development of a railway line and new railway stations also adds extra value to the land in the proximity to the development. Examples of economic models which have been used to finance the development of railways are in fact quite old, as is shown by the history of the United States of America (the Homestead Act) ${ }^{19}$ where railway companies were compensated for their investment in the railways by being given land in the proximity of the rail track. By developing the railway line, the value of the land bordering the line rose, and could be used to finance the construction of the line.

In Germany, other means of financing the development of an area also have a long history. This began with the introduction of a successful scheme of land value taxation in the German Protectorat Kiau Tchau (Tsjing-tao) in China. ${ }^{20}$ After this success, the idea started to attract attention in mainland Germany. By the end of 1910 no less than 652 municipalities and provinces in Germany had a land value tax. $^{21}$ The first German city to introduce such a tax was Frankfurt am Main in $1894 .^{22}$ The first tax levied was without success, but a renewed effort in 1904 met with more success. ${ }^{23}$

The land in Kiau Tchau was leased by Germany from China (compare Hong Kong and Macao) and not bought. Therefore it is not strange to find that the general taxation system distinguished between a tax on land, and a tax on the improvements of the land. ${ }^{24}$ This reflects proposals that had been developed earlier by Henry

\footnotetext{
16 Ibid., chapter 4.

17 Het Verband met Verbonden Partijen, page 3.

18 Ibid.,page 3.

19 The Homestead Act May 20, 1862. (U. S. Statutes at Large, Vol. XII, p. 392 ff.)

20 J.G. Backhaus, Land Value Taxation in Germany: Theoretical and historical issues (1997), Essay prepared for a Compendium on Land Value Taxation Around the World to be published on the occasion of the 100th anniversary of the death of Henry George.

21 Backhaus, page 9.

22 Ibid., page 10.

23 Ibid., page 10.

24 Ibid., page 12.
} 
George, an economist from New York. ${ }^{25}$ In his work George distinguished between land value and improvements to the land. In the case of Kiau Tchau this distinction made great sense. The implementation of the "Georgian Tax" in Kiau Tchau meant that $33,33 \%$ of the sales value of every piece of land property had to be paid to the government at the time of sale, with a deduction for the value of certain documented improvements, plus $6 \%$ of the total sales value. ${ }^{26}$ As a sort of pre-collection of the tax, each 25 years landowners had to pay one-third of the rise in value of the land. These obligations were not collected in the form of regular taxes, but in the form of mortgages held by the government, protected by the property title of the land.

We can now see how this system worked as a development strategy. From the start of the development process, the development authority, in this case the governor of Kiau Tchau, owned mortgages, the value of which depended on the success of the developments. These mortgages could also serve as a security for future credit. Therefore the funds for development existed from the start of the development activities, namely the moment at which a specific plan was presented and potential buyers were interested in the land that was described in the plan. This is a development strategy that can also be used in the same way with regard to the new railway lines and roads in Parkstad Limburg, or land in the neighbourhood of tourist attractions, industrial estates or nature reserves. It could also offer potential benefits for the neighbouring Aachen region in Germany, with the development of the Rhein Westfälische Technischer Hochschule (RWTH) and new housing developments in the north part of Aachen (Richterich).

The "Georgian" programme distinguishes between the "rent" of natural resources on the one hand, and the improvements to the resources on the other. ${ }^{27}$ The programme presumes that "rent" can be taxed completely, while improvements should be untaxed. This creates a tax base that can allow for economic development, with a special focus on economic efficiency. All these elements can be found in the system of real estate taxation in general in Germany, ${ }^{28}$ but play an even more important role in the interaction between income tax and investment projects of companies in certain assigned fields, such as the development of real estate, but also other fields like shipbuilding.

Such an assigned area for economic development could also be formed in the Parkstad/Aachen region, within the borders of the EGTC. This is a picture that is drawn by Mayor (Oberbürgemeister) Linden of Aachen in his plea to connect the city of Aachen with Parkstad Limburg under the title Charlemagne Region at a meeting in Heerlen on the 1 April 2009. ${ }^{29}$ His idea is that this cross-border region could obtain a special fiscal status, making it even more attractive to carry out projects on a European scale within the EGTC.

\footnotetext{
25 Henry George, Progress and Poverty, San Francisco, 1979, New York: Appleton, 1880 (2).

26 Backhaus, page 12.

27 Ibid., page 2.

28 Reginald Hansen, Die praktischen Konsequenzen des Methodenstreits: eine Aufarbeitung der Einkommensbesteuerung, Duncker \& Humbold, Berlin 1996.

29 Meetings and discussions on the Pact van Parkstad, 1 April 2009, Parkstad Limburg Theaters, Heerlen
} 
From a more defensive perspective, it is also good to keep the coherent idea of spacial development in mind. This is because development, disinvestments, additional write-offs and other developments influence the value of land and should be regarded from an integral administrative perspective. This coherence is also the basis for the counterbalancing of certain risks concerning spacial developments. This can be regarded as allowing solidarity between the several public parties involved in the Parkstad Limburg and Aachen region, but can also be seen as a potential incentive to policy making, because the advantages for the one, will also be the advantages for the other.

By choosing the centre of Heerlen, the central municipality in Parkstad Limburg, as a focal point for development, the value of land and the value of the real estate in this area will be influenced positively. However, in a situation of negative demographic change, as is occurring in the former coal-mining region of Parkstad Limburg, choices regarding which areas to develop will also lead to lower property values in areas where real estate is going to be demolished. In the EGTC all parties can put their cards on the table, and (non-)decision making and political tensions can be reduced to a manageable level. The EGTC will also enable the fair use of official instruments, equalization funds etc. to limit negative effects.

\section{Financial resources for development and restructuring}

There are various possibilities for raising investment funds to support the different development and restructuring projects, other than the acquisition of regular public and private money used to fund these kind of investments. A first additional possibility is to make use of a benefit-tax or exploitation regulation. Given that infrastructure development in the vicinity of the land will have external positive effects, fiscal regulation can (partly) tax the rise in the value of land. This is important in a development strategy, although in practice there is often much more attention given to negative external effects of such taxation, than for possibilities to bring returns to the original investor, such as a regional government or an EGTC. ${ }^{30}$ However, one should note that, under EU law, an EGTC cannot exercise powers conferred by public law, such as the levying of tax. ${ }^{31}$ Therefore, if this means of raising income is to be pursued within the EGTC, it must be carried out by the individual members, such as the local municipalities, or by national government. Nevertheless, an EGTC could provide the framework within which cooperation and agreement on such issues could be reached.

A second additional possibility for raising investment funds arises if we put the EGTC and the financial implications of an EGTC and its development and restructuring agenda in its own time frame. By this we mean that the development of the railway lines, motorways, renovation of housing in Parkstad Limburg, the development of new housing projects in Aachen-North, the enlargement and opening of tourist attractions, the development of the university campus around

\footnotetext{
30 Backhaus (1997).

31 Regulation (EC) No. 1082/2006, Article 4(4).
} 
Melaten and Westbahnhof in Aachen-West, the upgrading of the cross-border industrial area Avantis and the restructuring of other industrial estates, will take 30 or more years. ${ }^{32}$

Such a lengthy period of time is of great importance for long-term investors, like pension funds. In economically uncertain times, land is a relatively safe investment, because land cannot "disappear", like stocks and money can. For example, in the spring of 2009, the Dutch pension fund for civil servants (ABP), the second largest pension fund in the world, based in Parkstad Limburg, announced that it was looking for infrastructure projects in the Netherlands as long-term investment projects. ${ }^{33}$

Investment projects with a substantial size and many possibilities to diversify risks can provide a relative steady cash flow for long-term investors, like pension funds, resulting from availability payments ${ }^{34}$ for roads and railway lines, user fees for roads and railway lines, mortgages, rents, leases, entry fees, benefit-taxes and exploitation indemnities. This will give the different investment projects carried out within the EGTC a special collective value.

If we consider the development of different projects from a side-by-side and public-private partnership perspective, there can also be quite a few efficiency gains, that can serve as compensation for exploitation losses in other parts of the total development. Efficiency gains can provide the money to pay for several basic investments in railways lines and roads, the demolition of houses, the restructuring of industrial estates, and compensation for negative external effects.

A third additional financial instrument which can be used to raise investment funds has been described by Jurgen Backhaus of Erfurt University. Noteably, his analysis also concerns a cross-border project involving Germany, but in this case with Poland. Backhaus has described a financial instrument which could have been used to finance the construction of dikes and dams after the Oder-floods in 1997. ${ }^{35}$

In the summer of 1997, the Oder Valley experienced an almost unprecedented flood. By calling in the army, the German government prevented the dykes from bursting, yet massive floods occurred in neighboring Poland, as the River Oder is now the border between Germany and Poland.

(...)

The emergency occurred not only due to poor maintenance of dykes and dams under state socialism, nor only due to luvial rainfall, but in particular due to the neglect of forestation in the Silesian and Moravian mountains. Hence, preventing future floods will involve not only repairing and improving dykes and dams as well as the irrigation systems, but also and most importantly re-foresting and properly maintaining the forest in the Silesian and Moravian mountains.

\footnotetext{
32 Rekenkamercommissies Parkstad Limburg, Het Pact van Parkstad (2009).

33 NRC-Handelsblad, 25 April 2009, page 1.

34 Availability payments are payments from the regional governments to the financial institution that has financed the road construction. When the road is completed, it is available for the people to use, and to pay for this service the local government pays a rent.

35 J. Backhaus, "Land Rents and Ecological Crisis: The Case of the Oder River Valley", American Journal of Economics and Sociology, vol. 58, nr. 2, April 1999, pp. 249-252.
} 
As a consequence of drawing border lines during and after World War II, both the mountaintops and the rivers Oder and Neisse have become frontier lines, which implies that ecological entities have been dissected. Hence, what as a consequence of the Silesian war had become both an ecological and a political entity - the Kingdom of Prussia enclosing the relevant parts of the River Oder and most of its tributaries as well as the relevant mountaintops-has now lost its concomitant political authority to enforce the proper ecological management. Likewise, since the relevant jurisdiction has been lost, the tax base has likewise been lost that could allow for the clean-up effort of rebuilding dykes and the re-forestation of the mountains needed to repair the damage and prevent future flooding.

(...)

A solution to this problem can be found in the writings of Henry George (George, 1880). The funds required for the repair of damage; improvements of dykes, dams, and ditches; and the re-forestation of the mountaintops are available in the value of the improvements of lands thereby achieved. These improvements would accrue to the owners of land as an increase in the land rent without their own labor, and hence, according to the precepts of Henry George's "remedy," they would be subject to his single tax.

Since no political authority presently exists that could levy the tax, a substitute solution is called for. Through an international treaty, an Oder Authority can be set up, with very much the same statutes as the German-Polish Foundation. The Oder Authority's purpose would be the ecological management of the mountain ridge. To this end, it would have to acquire land and manage it, generating proceeds from the exploitation of woodlands and river sites. It could reclaim the land rent increase due to its activities through a scheme of options propagated in modern finance theory.

A call option gives its owner the right to buy stock at a specified exercise or striking price. Similarly, a put option gives the owner the right to sell at (an obviously lower) exercise price. The present owner of lowlands faces the prospect of either owning land that is going to be flooded frequently or owning land that will be protected from flooding, and the difference in the value of these two types of land is attributable to the activities that the Oder Authority envisioned. Hence, the authority can issue put and call options. It should actually have the exclusive right to do so. Farmers will be interested in selling land subject to frequent flooding and buying land protected from such peril. The authority itself controls the risk, and the value of the improvements must be at least as high if not in excess of the cost of making the improvements. Hence, the revenue source lies in selling the insurance (through put and call options) so as to assume the risk the landowners would like to discharge or transfer. Obviously, the authority will also buy up land at present market value, mortgaging it at close to 100 percent.

Therefore, when assessing investment projects and area development from a financial perspective, it is important that the value of the options identified above are considered in addition to the direct benefits of the project. The value of a put or call 
option can be calculated by professionals, and are possibly easy to rewrite in the case of real options on the land that result from the development of the infrastructure in Parkstad Limburg and Aachen. Special attention in this case should also be given to the pension funds, because they have a large amount of expertise on the calculation of the value of real options.

\section{The functioning of a cross-border authority}

Earlier in this paper we have noted that government investment could be earned back through macro-economic benefits, the rise in the value of land, and through the value of real options on the land in the investment areas. We have given attention to the role of a pension fund in financing the different developments over a long time period, both with regard to the coordination of the different projects, cash flows and investments, and in regard to the participation of several partners when executing the different project in public-private partnerships. Such a way of operating requires strong government, in addition to private parties which have access to large amounts of capital. Government must be able to set those fiscal and compensation measures that are necessary for the development of the area, to plan the development, to support the auditing on the project, and to provide the conditions for the conservation of property rights in the area, so that development, building, financing and maintenance can be coordinated simultaneously, and macro-economic costs and benefits can be combined together in an optimal way.

However if such a public entity (government) does not exist, because of competence and power struggles between different levels of government, property rights get diluted, and the long-term added value for investors will disappear. For example, if the new railway line between Heerlen and Aachen leads to a better access to the housing market in Parkstad Limburg, and, as a result there is an additional demand for 500 houses from the German side of the border, the cost of the restructuring in Parkstad Limburg will be reduced by $€ 35$ million through the sale of the extra houses. If we take a time period of 30 years, this means that, even with 1 million euro losses on the exploitation on the railway line each year, this will still result in a return on the investment.

Perhaps this example is a little too simplistic, but the power of this analysis is that the legal, fiscal, financial and public governance issues can be combined through an EGTC and area development in the Aachen-Heerlen (Parkstad Limburg) region. In this analysis we can learn lessons from the development strategy that was used in China 110 years ago.

The main task of an EGTC in this case would be to protect the unity of the property rights in the whole cross-border area, and to protect the value of the land. If those property rights were divided between several governments, the investments will always incur a loss, because the division of property rights will destroy the value of the possibilities for development, and the possibility for levying a land tax will disappear.

As long as the property rights of the land are divided between several authorities, or get diluted for other reasons, long-term investors will find it less attractive to 
become a partner in the Parkstad Limburg-Aachen EGTC. A cross-border integration of property rights has the political benefit that projects on both sides of the border can allow for internal compensation and differentiation of risks, and thus contribute to the wished-for cross-border solidarity. Moreover, individual developments can potentially benefit from a compensation fund set up within the framework of the EGTC, as is provided for in financial and investment standards. Without such solidarity schemes, big differences in wealth and income will develop between the municipalities in the region, and especially in Parkstad Limburg.

As we have seen earlier, the choice for a certain part of the region as a central point of development, will lead to a certain distribution of the (increased) value of the land, in comparison with when another choice is made. This difference may lead to political tensions, because the costs and benefits of restructuring will differ per municipality. These tensions can be changed, in a positive direction, if the property rights linked to development are organised by one public entity. This is a further reason to choose for one authority to regulate the whole restructuring of the Parkstad Limburg-Aachen region.

The Pact van Parkstad is an impressive agenda and a quick execution of this agenda requires a merger of all economic and spacial portfolios of the seven municipalities in Parkstad Limburg. This merger should be matched by a counterpart on the German side of the border. It is only in this way that the property rights for the whole restructuring area can be secured, and opportunities, threats, risks, profits and losses can be shared with each other and with as many private partners as possible. This can also lead to the establishment of a knowledge base for the large amount of work that has to be done concerning the different developments, and can lead to a large improvement in the knowledge of local government employees, especially those who work in small municipalities.

If an integral policy forms the necessary conditions for a successful, effective and efficient restructuring of the old coal mining area of Parkstad Limburg, then this can only be achieved by administrative, political and legal unity. The seven municipalities and the Province of Limburg can only achieve this by putting all their possessions in the form of land, development companies, land reserves, and other forms of real estate in one government company, in return for shares in this company. This will bring important opportunities. For example such an entity can qualify for a special fiscal status, that supports investment in certain buildings, field or areas by giving investors a special deduction from their income tax, as described by Reginald Hansen in the "die Anlagen" (Annexes) to Die praktischen Konsequenzen des Methodenstreits: eine Aufarbeitung der Einkommensbesteuerung. ${ }^{36}$

The Dutch and German authorities have already developed cross-border industrial estates, where companies situated in special industrial sites are still subject to their own tax authorities, although they are actually housed on the other side of the border. ${ }^{37}$ Two of these sites are based in the Parkstad Limburg-Aachen

\footnotetext{
36 Reginald Hansen, Die praktischen Konsequenzen des Methodenstreits: eine Aufarbeitung der Einkommensbesteuerung, Duncker \& Humbold, Berlin 1996.

37 Het Verband met Verbonden Partijen, page 26 and page 29.
} 
region: Industrial Estate Avantis in Heerlen/Aachen and the Eurode Business Centre, an office building build on the border of Kerkrade (NL) and Herzogenrath (D).

Although the possibilities for the Aachen-Parkstad region still have to be developed, given that the organisation of the Parkstad-Aachen EGTC is still in the development stage, there are different combinations of law and economics at stake. A key issue to be resolved concerns the location of the registered office of the EGTC, because when the registered office is based in Aachen, the whole EGTC area will fall under the jurisdiction of the German authorities, and when the registered office is based in Heerlen, the whole area will fall under Dutch jurisdiction. ${ }^{38}$ So far this matter is still undecided.

\section{Observations and conclusions}

The economic considerations in this article with regard to the Pact van Parkstad give a further insight to those factors that should be taken into account, when giving form and structure to an EGTC in the Parkstad Limburg-Aachen Region.

The first observation is that all the planned developments in the region are strongly connected to each other, so that it is preferable to consider these developments from an integral administrative perspective. This perspective also focuses attention on the need to enlarge the Pact van Parkstad in the Dutch part of the region to an EGTC covering the whole economic area of Parkstad-Limburg and Aachen. This is necessary both with regard to the Allied Parties that need to be established, as well as with regard to use of other cross-border legal instruments.

A cross-border authority is needed in order to connect the developments in Aachen with those in Parkstad Limburg, so that the whole region is able to share development risks, possibilities, and problems. Such an authority will come to quicker decisions and act from a common cross-border solidarity perspective.

The second observation is that an efficient and effective development of the region, with it new roads, railway lines, neighbourhoods, industrial estates, institutions and tourist attractions will have many implications for the use of land, that will stretch over a period of 30 years or longer.

Such a period of development for the restructuring of a region presents an interesting investment opportunity for a pension fund, such as ABP. However, this will only be an opportunity if the property rights on the land can be secured by a specific regional authority. This also applies without the involvement of ABP, or other investors, because efficiency reasons will require an integral overview of the whole development agenda on both sides of the border. Therefore it is important that the execution of the Pact van Parkstad and the EGTC allows for an integral bundling of all land possessions, including the development companies that are

\footnotetext{
${ }^{38}$ Although note that Regulation (EC) No.1082/2006 provides that Community (now EU) legislation on jurisdiction shall apply to disputes involving an EGTC (Article 15(2)). However, the Regulation itself provides that an EGTC shall be treated as an entity of the Member State in which it has its registered offices (Art. 2(1)). If EU law does not provide for the determination of jurisdiction, the competent courts for the resolution of disputes.
} 
already owned by government in that area, and the merger of all the civil service departments that are responsible for spacial, economic and building planning.

This third observation involves the need for the creation of the conditions for the application of innovative public-private partnerships, fiscal conditions to tax added value resulting from public investment, and the provision of revenue to cover exploitation losses, negative external effects, and other non-profitable investments, to supplement public money received from the governments in Maastricht, Düsseldorf, the Hague, Berlin and Brussels.

The fourth observation is that cooperation on a large scale can only be sustainable if the property rights of the investors can be secured on a long-term basis. The dilution of property rights, for example when participating local governments want to keep a part of the agenda to themselves for political reasons, will be fatal for the rest of the agenda, in terms of financing. From an administrative perspective, this implies that all the governments, including the provincial government in Limburg, will become participants in the Allied Parties included in the Pact van Parkstad and the EGTC, and that all parties will act accordingly to protect all the property rights.

On a short term basis the Pact van Parkstad and the EGTC requires the following actions:

1. Preparation for the merger of all local government departments dealing with spacial, economic and building affairs in the Dutch part of the EGTC, as well as civil servants from the Province of Limburg, into one public entity. The public entity should be structured in such a way, that it can secure the property rights on lands and development.

2. The parties to the public entity described under 1 should put all their belongings in terms of land and property on this land into the public entity in return for shares in this entity.

3. The foundation of an EGTC between Aachen and Parkstad Limburg.

4. The preparation of all kinds of financial activities needed to differentiate and distribute risks, and all necessary financing and treasury activities, that are connected to the integral development and restructuring agenda.

5. The preparation of public-private partnerships.

This article has provided some considerations concerning the Pact van Parkstad and the potential EGTC in the Aachen-Parkstad Limburg region from a law and economics perspective. Putting things into practice is normally not the work of academics, but for those politicians and civil servants who are directly involved on both sides of the border. Nevertheless we have seen in this article that the Pact van Parkstad and an EGTC have many economic and financial implications, which need to be considered if the agenda is to become a success. This success is attached to a global or cross-border vision of the future of the region in the European Union, which puts the role of borders into a special perspective. An EGTC and the redevelopment of a former old coal mining area is a project requiring real solidarity, sincerity and the willingness to share political power. Without those shared values it will be difficult to make the Pact van Parkstad and the EGTC a true success. Time will tell if such shared values exist and are sustainable. 
Acknowledgments Dr. Simon Duindam is grateful to Prof. Dr. J. Backhaus for giving him the opportunity to present this paper at the seminar and to the participants of the seminar for their helpful comments. Naturally all remaining errors are the responsibility of the authors.

Open Access This article is distributed under the terms of the Creative Commons Attribution Noncommercial License which permits any noncommercial use, distribution, and reproduction in any medium, provided the original author(s) and source are credited. 